\author{
제주도 해양레저장비산업 육성 방안에 대한 고찰 \\ 이영진 · 송영민 ${ }^{\dagger}$ \\ (경희대학교 - ${ }^{\dagger}$ 안양대학교)
}

\title{
A Study on the Development Strategy of Jeju Marine Leisure Equipment Industry
}

\author{
Young-Jin LEE $\cdot$ Young-Min SONG ${ }^{+}$ \\ (Kyunghee University $\cdot{ }^{\dagger}$ Anyang University)
}

\begin{abstract}
This study was to consider the development strategy of Jeju Marine leisure equipment industry for facilitating marine leisure tourism industry. For achieving this goal, the case studies related to domestic \& foreign marine leisure equipment industry, interviews of marine leisure equipment company, the contents of specialist consultation meeting were used in this study. The strategies for promoting were suggested in progress that step 1 was the expansion of maintenance infrastructure as of a port of call, step 2 was the establishing of marie leisure tourism image, step 3 was the integration of marine leisure equipment industry. More specific suggestions were followed. As an aspect of infrastructure, the expansion of management of marine leisure equipment such as yacht, development of marina having similar image of Jeju were suggested. As an aspect of law/institution, the development of financial support system on the marine leisure equipment, promotion of establishment of professional education institutions were suggested. As an aspect of contents/programs, the hosting the exhibition of marine leisure used equipment of international trade, the development of environmental-friendly program associated with cruise were suggested, Finally, as an aspect of promotion/marketing, the promotions linked with drama \& movie industry, the strategy of improvement of negative image to the yacht industry were suggested.
\end{abstract}

Key words : Marine leisure tourism, Marine leisure equipment industry, Jeju, Marina, Yacht

$$
\text { I. 서 론 }
$$

전 세계적으로 해양관광에 대한 수요가 급증하 고 있다. 국민소득의 향상과 레저관광에 대한 요 구의 다양성, 육상관광지의 포화상태 등은 국민 들의 관광에 대한 관심을 육상에서 해양으로 전
환을 유도하였고 학계에서도 기존 시설을 이용한 해양 체험관광 활성화 필요성이 지속적으로 대두 되고 있다(이영진 - 송영민 이광표, 2011; 지삼업 · 김용재·이재형, 2005). 특히 세계적으로 해양 레저 관광산업분야는 10 년 내 4 배 이상 성장할 것으로 예상하고 있으며 2016년 해양레저관광수

† Corresponding author : 032-930-6017, songymin@anyang.ac.kr 
익 약 48 조원, 103 만 명 고용창출이 예상되고 있 다(해양한국, 2006). 세계 해양레저장비시장도 매 년 100만 척(470억불 상당)의 신규 수요가 발생 (지식경제부, 2009a)할 만큼 급성장하고 있다. 또 한 조선·조선기자재, 해양스포츠, 전시산업, 금 융·보험산업 등 전후방산업 연관효과가 크다고 할 수 있다(지식경제부, 2009b). 한 예로 아메리 카컵스 요트대회는 경제적 파급효과가 10 조원으 로 올림픽 16조원, FIFA월드컵 13조원(해양한국, 2010)에 이어 3 번째로 큰 시장임을 감안할 때 해 양레저산업은 지역뿐만 아니라 국가경제에도 많 은 기여를 할 것으로 예상할 수 있다.

특히 제주도는 국내 최고의 휴양관광지로 아름 답고 우수한 해안경관과 청정한 해양자원과 세계 자연유산 등 풍부한 관광자원의 매력을 보유하고 있어 해양레저산업의 성장 잠재력이 매우 높다고 할 수 있다. 또한 인근 전남의 2012년 여수세계 박람회(EXPO)의 개최는 제주도의 해양레저관광 산업을 활성화할 수 있는 기회가 될 수 있다. 따 라서 제주도는 증가하는 해양레저관광시장에 적 극적으로 대비할 필요가 있다.

하지만 국내 상황은 해양레저관광객의 수요를 대비할 수 있는 기반시설과 인프라의 부족으로 해양레저산업의 활성화를 위해 해결해야할 문제 점들이 많다(박성현, 2005). 이러한 문제는 2차 산업 기반이 취약한 제주도에도 큰 제약으로 작 용하고 있다. 따라서 본 연구는 먼저 국내 해양 레저장비산업의 현황 및 문제점에 대해서 생각해 보고, 선진 해양레저장비산업의 국내·외 사례 고찰, 전문가들의 심층 면접을 바탕으로 제주도 해양레저장비산업의 육성 전략을 제안하는데 목 적이 있다.

\section{II. 해양레저장비 산업 개관}

\section{1. 해양레저장비산업의 개념 및 종류}

해양레저는 "일상 생활권을 벗어나서 기본적으
로 위험 감수 동기를 내재하고 여행, 휴식, 건강, 위락, 해양 스포츠 등 레저를 즐길 목적으로, 해 양과 인접하고 해양과 관련된 곳에서 제공되는 자연자원과 인공적 자원을 감상, 활용하거나 지 역 사회의 해양레저장비 및 어촌 문화를 체험하 기 위해 행하는 활동 행태"로 정의한다(이영진, 2009: 21). 또한 해양레저장비산업은 내수면과 해 수면에서 해양 레저 활동을 목적으로 사용하는 장비와 그와 관련된 부품 및 용품을 제작하는 산 업을 의미한다(중소조선연구원, 2010). 광의의 개 념에서는 해양레저장비의 수송기구, 전문생산설 비, 유지보수, 설비, 마리나 설치 및 운영산업, 서 비스 산업 등 해양레저장비생산과 직접적으로 연 관된 업종을 포함할 수도 있다(월간 해양과조선, 2011; 중소조선연구원, 2010).

해양레저장비는 수상 레저 안전 법에서 '수상 레저기구'로 분류하고 수상레저 활동에 이용되는 선박이나 기구로서 대통령령으로 정하는 것을 칭 한다(법률지식정보시스템, 2012). 국내 해양레저 장비 분류는 수상 레저 안전 법 제 2 조 제 3 항 및 동법 시행령 제 2 조에 의거하여 <표 $1>$ 에 나타난 15종으로 구분하고 있고, 그 밖에 수상레저기구 와 비슷한 구조나 형태 및 운전방식을 가진 장비 중 국토해양부령으로 정한 것을 말한다(법률지식 정보시스템, 2011).

해양레저장비산업은 이러한 해양레저장비를 모 두 총괄하는 산업으로 요트 등 선박 및 선박부품 제조 산업, 마리나 설치 및 운영산업, 서비스 산 업 등을 모두 포함하고 있다(부산발전연구원, 2009). 이러한 해양레저장비산업은 제품별로 적용 되는 소재, 생산 공법, 부품 등 적용되는 기술이 다양하여 종합 산업적 성격을 보이고 있으며, 전 후방 산업과의 관계가 밀접하여 다른 산업에 미 치는 파급효과가 큰 신수종(新樹種)산업1)이라고 할 수 있다. 해양레저장비산업의 전후방산업으로

1) 신수종(新樹種)은 새로운 종류의 나무를 말하며, 신수종산 업은 미래 산업을 이끌어 갈 만한, 새로 육성할 유망한 산 업을 의미한다(네이버백과사전, 2012, 검색어: 신수종사업). 
는 중소조선산업, 조선기자재산업, 해양관광산업, 스포츠산업, 전시산업, 금융보험산업, 요트산업, 중계산업, 목재산업(소재산업), 부품소재산업 등 (중소조선연구원, 2008:5)이 있다.

<표 $1>$ 해양레저장비의 종류

\begin{tabular}{|c|c|c|c|}
\hline No & 품 명 & $\mathrm{No}$ & 품 \\
\hline 1 & $\begin{array}{c}\text { 모터보트 } \\
\text { (Motor Boat) }\end{array}$ & 9 & $\begin{array}{c}\text { 조정 } \\
\text { (Rowing Board) }\end{array}$ \\
\hline 2 & 요트(Yacht) & 10 & 카약(Kayak) \\
\hline 3 & $\begin{array}{c}\text { 수상오토바이 } \\
\text { (Personal Watercraft) }\end{array}$ & 11 & 카누(Canoe) \\
\hline 4 & $\begin{array}{c}\text { 고무보트 } \\
\text { (Rubber Boat) }\end{array}$ & 12 & $\begin{array}{c}\text { 워터슬래드 } \\
\text { (Water Sled) }\end{array}$ \\
\hline 5 & 스쿠터(Scooter) & 13 & $\begin{array}{c}\text { 수상자전거 } \\
\text { (Water Boat) }\end{array}$ \\
\hline 6 & $\begin{array}{l}\text { 호버크레프트 } \\
\text { (Hovercraft) }\end{array}$ & 14 & $\begin{array}{c}\text { 서프보드 } \\
\text { (Surf Board) }\end{array}$ \\
\hline 7 & 수상스키(Water Ski) & \multirow{2}{*}{15} & \multirow{2}{*}{$\begin{array}{c}\text { 노보트 } \\
\text { (Paddle Boat) }\end{array}$} \\
\hline 8 & 페러세일(Para Sail) & & \\
\hline
\end{tabular}

\section{2. 국내 해양레저장비 산업 현황 및 문제점}

국내 해양레저장비 생산업체는 총 50 여 개 업 체이고, 고용 인력은 700 여명 등인데, 이용규제와 제도 미비로(지식경제부, 2010; 중소조선연구원, 2010)로 해외에 비해 부족한 실정이다. 2005년부 터 자전거 해양레저장비산업 육성사업, 2009년부 터 해양레저장비산업육성사업을 통한 레저선박 분야 기술개발을 추진하고 있으며(지식경제부, 2010), 2008년 중소 조선 연구원 해양레저장비개 발센터 구축을 통해 업계를 지원하고 있다(지식 경제부, 2010).

국내 해양레저장비 산업 수요 현황을 살펴보면, 매년 1억 1만여 명이 해수옥장을 이용(2005년 해 수욕장 이용객, 매년 $8 \%$ 정도씩 증가 추세)하고 국내 해양레저 면허취득자가 2000년 6,966명에서 2008년 약 6 만 5 천명으로 10 배 정도 증가 추세이
다. 또한 해양레저-스포츠 관련 단체나 동호회 의 수요도 증가하고 있다(제주특별자치도의회 농 - 수·축·지식 산업위원회, 2010; 중소조선연구 원, 2008).

해양레저장비를 공급하는 국내 생산업체는 주 로 해안선에 인접한 지역일수록 요트, 모터보트 등 대형장비를 생산하는 업체가 밀집되고, 내륙 지역일수록 고무보트, 카약, 카누 등 소형장비 생 산업체가 밀집되는 특성이 있다(중소조선연구원, 2010). 현재 국내에서 생산중인 해양레저 장비는 요트, 모터보트, 고무보트, 카약, 카누, 워터 슬레 드, 수상자전거, 서프보드, 노보트로 약 10여종이 고 레저보트에 필요한 160마력 이하 소형 고속엔 진 대부분은 수입에 의존하고 있는 실정이다(중 소조선연구원, 2010).

국내 해양레저장비산업 생산기반은 대부분 중 소형 조선소이며, 국내 중소형 조선소는 2006년 현재 105개사에 이르고, 관련 부품, 구성품 생산 가능한 조선 - 자동차 기자재 업체는 200여 개 업 체 정도이며(부산발전연구원, 2009; 한국조선공업 협동조합, 2012), 이중 순수 요트 및 보트 생산 가능 업체는 40 여개, 부품 및 수리 업체 50 여개, 엔진 및 항해/ 통신 부품업체가 50여개이고 해양 레저장비개발센터 등은 5 개 기관이 있다(중소조 선연구원, 2010).

국내의 해양레저장비산업은 점진적으로 발전하 고는 있지만 아직 태동기로 전문 인력 및 생산업 체 부족, 해양레저 관련 인프라 부족, 관련제도의 모호성 등 해결해야할 문제점들이 많다(박성현, 2005; 부산발전연구원, 2009; 월간 해양과조선, 2011; 지식경제부, 2010). 대표적으로 해결해야할 문제점은 마리나 확대, 규제간소화, 운행시간 제 한 완화(일몰 후 허가), 입출항 신고절차 간소화 (원스톱 서비스), 세제감면, 금융상품 개발, 레저 선박 등록세 부담 완화, 레저선박 렌트제도 도입 등 금융상품 개발, 대형조선업계 및 자동차업계 와의 연계를 통한 기술개발 지원, 지역대학 및 국제교류 등을 통한 설계·생산 인력 양성사업 
등이라고 할 수 있겠다.

\section{3. 제주도 해양레저장비 산업 유치 여건 및 환경 분석}

제주도는 동북아의 중심지로 해양레저를 즐기 기에 충분한 잠재력을 가지고 있다. 사면이 바다 로 둘러싸여 우수한 해안경관을 가지고 있고, 연 안 정착성 돌고래가 서식하고 민간투자에 의한 요트투어 등이 운영 중이다. 또한 한라산의 생물 다양성 등 풍부한 세계자연유산을 가지고 있다. 이러한 특징들은 제주도 해양레저관광산업에 충 분한 경쟁력이 될 수 있다.

하지만 도민의 해양레저관광에 대한 관심과 참 여가 미흡하고 내륙관광 중심의 정책으로 투자 우선순위에서 밀리는 단점도 있다. 또한 마리나 관리 및 운영 등을 맡을 전문 인력도 부족하고 제대로 갖춰진 해양레저 시설 및 인프라 등이 부 족하다. 또한 제주도에서 해양레저장비산업의 가 장 큰 단점은 제조업이나 조선업 등 해양레저장 비 관련 사업체가 부족하다는 것이다. 구체적으 로 살펴보면, 외부적인 위협요인으로 요트 등 해 양레저관련 제도가 일원화되어 있지 않고 마리나 조성 등과 관련된 규제 등이 미비하다. 요트 소 유자에 대한 부정적인 인식 등은 해양레저산업의 활성화에 위협요인으로 작용하고 있다. 특히, 경 기도, 부산, 경남 등 해안을 끼고 있는 지자체에 비해 후발주자로서의 한계를 안고 있다. 이러한 한계에도 불구하고 중앙정부의 요트산업 육성에 대한 관심, 마리나 항만조성 및 관리 등에 관한 법률 제정, 농림수산식품부의 다기능 관광어항 정책, 해양레저관광 및 여가-건강 등 웰빙에 대한 국민의 관심증가 및 수요 증대, 전문 인력양성 프로그램 개발 및 시행(아카데미, 학교운영), 2012 년 여수세계박람회 개최, 관광-레저형 생활패턴 의 선호 추세와 해양레저산업개발 증대 추세, 해 양레저스포츠 개최 등은 지역경제 활성화 및 지 역브랜드 홍보에 기여할 것으로 판단된다. 제주
도도 2차 산업의 불모지라는 단점에도 불구하고 지리적, 자연적 장점과 최근 해양레저관광에 대한 관심 증가에 힘입어 국내 최대의 해양레저장비 생산지역이 될 수 있을 것이다(제주의소리, 2010).

\section{III. 연구 설계}

본 연구는 제주도 해양레저장비 산업의 성공적 인 유치를 위해 사례 연구방법을 통해 전략방안 을 제안하였다. 이를 위한 자료원은 1 차적으로 문서정보를 활용하였고 2차적으로 구조화된 조사 지를 만들어 집중 인터뷰를 통해 자료를 수집하 였다. 3차적으로 개방적 형식의 인터뷰를 통해 제주도 해양레저장비산업 육성방안을 모색하였 다. 문서정보는 국-내외 해양레저장비관련 보고 서, 내부기록, 신문기사, 인터넷 자료 등을 검토 하였고 구조화된 집중 인터뷰는 문서정보 검토를 통해 해양레저장비 육성관련 내용으로 구성된 구 조화된 조사지를 이용하여 국내 관련 기업 대표 와 인터뷰를 진행하였다. 마지막으로 1,2 차적으 로 수집된 자료를 정리한 후 해양레저관광 및 레 저장비 관련 전문가 자문회의를 실시하여 의견을 수집하는 과정을 거쳤다(Yin, 2003).

<표 2> 조사 방법

\begin{tabular}{l|l|l|l}
\hline \multicolumn{1}{c|}{ 단계 } & \multicolumn{1}{|c|}{ 자료원 } & \multicolumn{1}{|c|}{ 자료 형태 } & 자료수집방법 \\
\hline \hline $\begin{array}{l}1 \text { 차 } \\
\text { 조사 }\end{array}$ & 문서정보 & $\begin{array}{l}\text { 보고서, 내부 } \\
\text { 기록, 인터넷 } \\
\text { 자료 등 }\end{array}$ & 문헌 검토 \\
\hline $\begin{array}{l}2 \text { 차 } \\
\text { 조사 조 화 된 }\end{array}$ & $\begin{array}{l}\text { 인터록물 } \\
3 \text { 차 }\end{array}$ & $\begin{array}{l}\text { 개방형 인 } \\
\text { 조승면접 } \\
\text { 인터부 자료 }\end{array}$ & $\begin{array}{l}\text { 전문가 자문 } \\
\text { 회의 }\end{array}$ \\
\hline
\end{tabular}

본 연구에서 제안하는 사례는 해양레저장비 중 요트를 중심으로 고찰하였다. 국내 사례는 경상 남도, 국외는 뉴질랜드를 살펴보았다. 구체적으 로, 요트산업 주요정책과 법 및 제도, 홍보 및 마 케팅, 기반시설, 인력 양성 등을 위주로 살펴보았 
다. 인터뷰조사는 제주도에 해양레저장비산업 유 치 시 문제점이나 추진 방향등을 도출하기 위하 여 정부의 지원 및 지자체 육성 정책, 인력 양성 및 확보 방안, 주요 수요시장(국내외 수요), 홍보 시장 및 유치 목표시장, 적정 부지, 해양레저장비 업체 유치 시 가장 중요하게 고려해야 할 사항 및 요구사항, 시설 및 인프라, 안전대책(보험 등) 등 에 관하여 조사하였다. 조사 업체는 참여 연구진 과 자문위원들로부터 추천받은 부산의 K_FRP산 업, 경남의 $\mathrm{H}$ 조선, 전남의 $\mathrm{Y} \_\mathrm{In}$, 제주의 L_Marine을 대상으로 조사를 진행하였다. 조사 방법은 직접 회사 대표자를 대상으로 인터뷰를 통한 1:1 심층 면접조사를 실시하였다.

마지막으로 전문가 자문회의에서는 해양레저 및 해양레저장비 관련 자문위원 3 인의 의견을 종 합하여 정리하였다. 주로 제주도에 해양레저장비 산업 유치 시 문제점이나 방향 등을 중점으로 회 의를 진행하였다. 주요 조사 내용은 '제주 해양레 저장비 산업의 방향', ‘제주 마리나 항 개발 방 향', '해양레저관광 수요 장려 방안', '중앙정부의 지원 유도 및 인력 양성 방안', '해양레저장비 업 체 유치 시 주의사항'에 관해 조사하였다.

\section{IV. 해양레저장비 산업 조사 분석 결과}

\section{1. 해양레저장비 산업 관련 국내·외 사례}

최근 선진국들은 소득수준의 증가에 따른 레저 및 관광 산업에서 해양의 비중이 클 것으로 예상 하고 있다. 선진 지역 보트산업의 주요 특징은 보트산업의 파급효과에 대한 인식이 확산되고 있 다는 점이다. 보트산업은 자동차산업처럼 전후방 산업효과로 인해 선진국들은 차세대 고부가가치 산업으로 보트산업 육성에 많은 투자 및 정책적 고려를 하고 있다. 한편으로는 글로벌 경기침체 로 인한 일반 레저보트 시장과 최근 성장세를 보 이는 슈퍼보트(메가 요트산업) 시장으로 이원화
되고 있다. 이러한 전망은 조선업계에서 세계 1 위라고도 할 수 있는 국내 시장에는 기회가 될 수 있다. 또한 세계 주요국의 해양레저장비산업 주요 정책 방향은 친환경 장비산업(미국의 클린보 트법 등), 국제박람회, 규제 완화, 기술 개발, 인력 양성(호주의 Action Agenda) 등을 주로 지원하는 추세이기 때문에 우리나라도 이러한 추세에 발맞 출 필요가 있다(코트라, 2009).

이에 본 연구는 제주도 해양레저장비산업 육성 을 위해 세계 주요국의 주요 정책방향을 살펴보 고(<표 3> 참조), 국내는 경상남도, 해외는 해양 레저산업으로 유명한 뉴질랜드의 요트산업 육성 방안에 관해 고찰하였다.

<표 3> 세계 주요국 해양레저장비 산업 주요 정책

\begin{tabular}{|c|c|}
\hline 국가명 & 주요 정책 방향 \\
\hline 미국 & $\begin{array}{l}\text { - [클린보트법 2008]을 통해 레저선 } \\
\text { 박에 대한 환경기준 적합 허가증 } \\
\text { 발급의무 면제 혜택 } \\
\text { - 주(州) 단위 산업지원 확대 }\end{array}$ \\
\hline 프랑스 & $\begin{array}{l}\text { - 경쟁력 강화지구 창설을 통한 기 } \\
\text { 술개발 지원 } \\
\text { - 레저선박 정박지 구축 및 국제박 } \\
\text { 람회 개최 지원 }\end{array}$ \\
\hline 호주 & $\begin{array}{l}\text { - 해양산업발전을 위한 [Action } \\
\text { Agenda] 발표(2004년) } \\
\text { - 보트산언단지 조성, 규제완화, 기 } \\
\text { 술개발 지원, 인력양성 지원 }\end{array}$ \\
\hline 대만 & $\begin{array}{l}\text { - 신다 요트산업단지 조성 } \\
\text { - 요트산업인재양성 3개년 프로 젝트 } \\
\text { 를 통한 전문인력 양성 }\end{array}$ \\
\hline
\end{tabular}

자료: 최영근, 이영진(2011: 74).

가. 경상남도 요트산업 육성방안 사례2)

경상남도에서 요트산업을 육성하기 위해 추진 중인 사업은 '대한민국 국제요트대전', ‘경남 요트 스쿨 설립 운영', ‘마리나 시설 조성', ‘요트산업 클러스터 조성', '요트제작 기업체 육성 및 유치',

2) 경남발전연구원(2007; 2009), 최영근 - 이영진(2011)의 내용 을 참고로 연구자 재구성. 
'아메리카스컵(America's Cup) 도전을 위한 역량 구축'을 포함한 6 개의 범주로 구분할 수 있다.

\section{A. 주요정책과 제도}

경상남도는 요트산업 육성을 위해 2020년을 목 표연도로 단계별 육성전략을 추진 중이다. 요트 인구 저변 확대와 국민인식 제고, 요트산업 기반 시설 조성, 요트산업을 성장 동력 산업으로 육성, 아메리카스컵 도전을 위한 역량 구축을 구체적인 정책목표로 설정하였다. 단계별로는 1 단계는 2007 2009년까지 요트 등의 해양레저 붐 조성시 기이고 이미 진행이 되었다. 2단계는 2010 2014 년까지 요트 기반시설 및 생산시설 확충기로 인 프라나 기반 시설 등에 집중적으로 투자하고 있 다. 2015 2020년까지 3단계에서는 생산기술을 제 고하고 국제적 위상을 구축하는 시기로 경상남도 의 요트를 브랜드화 하는 시기로 설정하고 정책 을 추진하고 있다(경남발전연구원, 2009).

또한 경상남도는 요트산업을 체계적으로 지원 하기 위해 '경남요트산업육성조례'를 2008년 11월 13 일 제정함으로써 경남의 요트산업 육성을 위한 법적기반을 마련하였다. 주요 내용으로는 종합계 획 수립 시 시와 군이 계획을 연계하고 요트산업 자문위원회를 만들고 마니라조성, 교육 및 강좌 개설, 요트경기대회 개최, 요트선수단 구성 및 운 영 등의 요트산업 육성지원에 관한 내용, 요트학 교의 설치 및 운영 등에 관한 내용, 보조금 등의 지원과 부담금 등의 감면 내용을 담은 재정지원 으로 구분되어 있다.

\section{B. 요트산업관련 홍보 및 마케팅}

경남에서 요트산업을 홍보하고 마케팅하기 위 해 중요하게 생각하는 것은 국제대회의 개최이 다. 특히, '대한민국 국제요트대전'은 경남의 해양 레저 전진기지화, 요트인구의 저변 확대, 국민인 식제고를 위해 2007년부터 개최되었다. 3 번의 개 최가간동안 분산개최로 효율성이 떨어지고 관람 객들의 불편으로 2010 년부터는 '대한민국 국제보 트쇼'로 명명하고 고성군 당항포 관광단지 일원
에서 개최되었다(뉴시스, 2008.11.03.). 또한 세계 유명한 요트대회 참가를 위해 '아메리카스컵 도 전을 위한 역량구축' 사업도 추진하고 있다. 2020 년 아메리카스컵 대회를 경남에서 개최하기 위해 경남도내 중소형 조선소를 대상으로 선진지역 견 학 및 기술제휴 지원을 계획하고 있다.

C. 기반시설

인프라 및 시설은 2008 2020년 까지 연안 8개 시·군(마산, 진해, 통영, 사천, 거제, 고성, 남해, 하동)에 국비와 도비 등의 예산을 투입하여 총 약 1,386 척을 계류 시킬 수 있는 요트계류장 및 마리나 시설을 설치할 계획이다. 현재는 통영, 진 해, 사천, 거제 4 곳이 운영 중이다. 또한 요트산 업 클러스트 조성을 위해 2009 2015년 까지 통영 시 일원 약 26 만 $\mathrm{m}^{2}$ 부지에 요트 생산단지, 요트 스쿨, 요트전시관, 박물관, 첨단요트사업기술연구 센터 등을 조성할 계획이다. 이를 위해 경상남도 는 정부의 투자를 집중유도하고 이주 직원의 주 거와 교육, 의료, 문화생활 등의 인프라 전반을 공급할 필요가 있음을 제안하고 있다.

요트제작관련 사업장은 경남이 1개사로 미미한 실정이어서 요트제작 기업체를 적극적으로 육성, 유치하려는 전략을 취하고 있다. 구체적으로 파 격적 인센티브를 제공하여 국내외 요트제작업체 를 유치하고, 미국, 유럽, 호주 등에서의 투자유 치 활동을 강화하는 전략을 추진하고 있다. 특히 전남 소재 푸른중공업은 사업장이 협소한 문제점 을 해결하고 요트사업부문의 확장계획에 따라 요 트건조장을 거제 장목으로 이전할 계획을 추진하 였고, 현재 1 만 8 천 $\mathrm{m}^{2}$ 의 부지매입을 완료하고 2008년 11월말 허가를 모두 취득한 상태이다(최 영근 - 이영진, 2011). 푸른중공업은 국내 유일의 슈퍼요트 제작 업체로써 세계시장에서 일정 수준 인정을 받고 있어 경남 거제로 이전 완료 시 경 남의 요트산업 발전에 기여도가 높을 것으로 예 상할 수 있다. 이를 위해 공장부지에서 항구까지 의 진입로 개설 등의 문제가 시급한 것으로 경남 
도는 파악하고 있다.

D. 인력 양성

요트 인력양성을 위해 경상남도는 요트 스쿨을 설립 운영하고 있다. 경남지역에서 수상레저 면 허취득 현황을 살펴보면, 2001 2007년까지 연 평 균 $7.1 \%$ 로 전남에 이어 두 번째로 높은 증가율을 보이고 있다. 이러한 관심과 더불어 현재 경상남 도는 경남요트교육통합시스템을 만들어 각 지역 의 요트학교와 연계하여 체계적으로 인력을 양성 하고 있다(경남요트교육통합시스템, 2012). 2011년 운영 중인 요트학교는 거제, 남해, 고성 당황포, 진해, 통영 5곳이고, 요트 인력 양성을 활성화하 기 위해 도립대학을 이용한 요트관리 및 생산, 수리전문가 양성도 진행하고 있다(최영근-이영 진, 2011).

나. 뉴질랜드 요트산업 육성방안 사례3)

\section{A. 주요정책과 제도}

뉴질랜드는 세계 최대, 최고의 요트왕국임을 입증하듯이 제조업 중 유일하게 수출경쟁력을 가 진 산업이 보트산업이다. 수출 경쟁력을 높이기 위해 각종 보트관련 규제를 완화하여 호화 슈퍼 요트 최대 수리국으로 자리매김하고 있다. 세계 에서 가장 크고 호화로운 요트 가운데 하나인 아 데나(Athena) 메가 요트도 2011년 2월 오클랜드 웨스트헤븐 마리나에 정박해서 수리(굿데이, 2011)를 하였을 정도로 요트관련 기술이 뛰어난 국가이다. 특히, 유연한 생산과정과 질 높은 기술 노동자는 뉴질랜드 해양산업의 핵심역량으로 작 용하고 있다(UK Trade \& Investment, 2006). 낙 농국가인 뉴질랜드는 제조업 중 보트산업이 수출 경쟁력을 보유한 거의 유일한 산업으로, 제주특 별자치도와 유사한 지역적 특성을 가지고 있어, 제주도 해양레저장비산업의 발전 모델로 활용할 수 있을 것이다.

뉴질랜드의 요트장비 관련 제도로는 요트 면허

3) 본 자료는 코트라(2009: 57-61) 보고서의 오클랜드 $\mathrm{KBC}$ 가 제공한 자료와 최영근, 이영진(2011)을 참고로 재구성함.
제도 및 등록의무 제도가 없고, 모터보트 면허로 요트 운행이 가능하다. 요트 클럽 활동 시 마리 나 클럽 가입이 필요하고 계류장 입출항을 자율 통제에 맡겨 사용료 납부 후 보안감시 및 전기, 수도 등의 혜택을 제공하고 있다. 사용료를 납부 하면 장비위탁관리, 장비분실보상, 자연재해보상 등의 혜택을 받을 수 있고 청소년이 계류시설 이 용 시 비용을 할인해주고 있다.

B. 기반시설

보트산업 유관업체는 본체 또는 부품 제조, 설 계, 광고업 등을 망라하여 총 545 개사가 뉴질랜 드보트산업협회(MIA; Marine Industry Association) 에 등록되어 있다. 이들 대부분이 종업원 수 9명 안팎의 가족기업 형태로 운영되고 있고, 특히, 뉴 질랜드의 보트 관련 중견기업인 Alloy Yachts, Salthous Marine 등은 세계적으로 유명한 슈퍼요 트 제조업체로서 규모가 탄탄하고 슈퍼요트 제조 능력은 2006년 9위에서 2007년 7위로 도약하였 다. 연관산업 분야별(2007년)로 보트 제조 $47 \%$, 부품 $29 \%$, 정박관리 및 광고 등 서비스 $16 \%$, 수 리업 약 $8 \%$ 정도로 파악된다.

\section{2. 심층면접조사 사례 연구 분석}

가. 심층면접조사 대상 업체 일반 현황

본 연구는 해양레저장비업체의 현 상황과 향후 발전을 위한 정부의 지원 등에 관한 내용을 조사 하기 위해 해양레저장비를 생산하는 업체 3곳의 대표를 만나 인터뷰를 실시하였다. 업체의 주요 생산 품목은 $\mathrm{FRP}$ 제품과 선박건조 및 수리 등이 었고 해양장비를 생산하는 업체 3곳 모두 생산직 에 비해 연구 개발 직이 많이 부족한 상태이다.

나. 심층면접조사 분석 결과

해양레저장비관련 업체들의 인터뷰 분석결과 첫째, 정책적 지원에 관해서는 우선적으로 기술 개발을 위한 정부의 지원을 원하고 있었다. 지방 자치 단체가 업체 유치를 위해서는 공장 용지확 보나 인건비 등을 한시적으로나마 지원할 수 있 
<표 4> 심층면접 대상 업체 현황

\begin{tabular}{|c|c|c|c|c|}
\hline 회사명 & 소재지 & 주요 생산 품목 & 총자산 & 인력현황 \\
\hline $\begin{array}{l}\text { K_FRP } \\
\text { 산업 }\end{array}$ & $\begin{array}{l}\text { 부산시 } \\
\text { 강서구 }\end{array}$ & $\begin{array}{l}\text { 일반 } \mathrm{FRP} \text { 제품과 선박건조(레 } \\
\text { 저보트 등) 및 수리(개조)전문 } \\
\text { 업체, 요트제조전문 업체 }\end{array}$ & $70 \sim 75$ 억 & $\begin{array}{l}\text { 대표 1명, 생산직 20명, 영업 } 1 \\
\text { 명, 사무직 8명, 연구 개발직 } 1 \\
\text { 명 등 } 30 \text { 명 }\end{array}$ \\
\hline $\mathrm{H}$ 조선 & $\begin{array}{l}\text { 경상남도 } \\
\text { 사천시 }\end{array}$ & 선박건조(요트 및 보트 등) & 80억 & $\begin{array}{l}\text { 생산직 30명, 영업/사무직 5명, } \\
\text { 연구 개발직 5명 등 } 40 \text { 명 }\end{array}$ \\
\hline Y_In & $\begin{array}{l}\text { 전라남도 } \\
\text { 영암군 }\end{array}$ & 요트 건조, 수리, 판매, 디자인 & 8억 & $\begin{array}{l}\text { 생산직 4명, 영엽직 } 1 \text { 명, 사무직 } \\
2 \text { 명, 연구개발직 1명 등 } 8 \text { 명 }\end{array}$ \\
\hline L_Marine & $\begin{array}{l}\text { 제주시 } \\
\text { 구좌읍 }\end{array}$ & $\begin{array}{l}\text { 전동 요트, 전동 파티바지 등 } \\
\text { 선박 제조와 신개념 피셔리나 } \\
\text { 인 테마파크 운영 }\end{array}$ & - & ( \\
\hline
\end{tabular}

<표 5> 심층면접조사 분석 결과

\begin{tabular}{|c|c|}
\hline 구분 & 분석 내용 \\
\hline $\begin{array}{l}\text { 정책적 } \\
\text { 지원 }\end{array}$ & $\begin{array}{l}\text { - 소비 촉진책 마련을 위한 국내 소비 장려 정책 마련 } \\
\text { - 자체 연구를 진행할 수 있는 정부의 연구 개발비 보조 } \\
\text { - 어민들과의 마찰을 해결할 수 있는 방안과 어민의 해양레저산업 마인드 형성을 위 } \\
\text { 한 교육 실시 } \\
\text { - 정부 및 지방자치단체의 세제와 제도의 현실적인 지원 필요(인건비, 용지인허가, 인 } \\
\text { 센티브, 환경을 고려한 부지 제공 등) }\end{array}$ \\
\hline 법/ 제도 & $\begin{array}{l}\text { - 보험제도 개선(자선 보험료 인하, 해양레저장비 보험관련 법 개정 } \\
\text { - 해양레저장비 제도 간소화 및 규제완화(출입항 신고, 요트구입 세금 인하, 해양레저 } \\
\text { 장비산업 지원조건 및 신고 절차 간소화 등) } \\
\text { - FRP 폐기에 대한 환경적 규제 문제 해결(환경오염 재료 공정 외주) } \\
\text { - 개인 면허제도 강화를 통한 안전 불감증 예방 }\end{array}$ \\
\hline $\begin{array}{l}\text { 콘텐츠, } \\
\text { 프로그램 } \\
\text { 및 운영 } \\
\text { 시스템 }\end{array}$ & $\begin{array}{l}\text { - 해양레저산업, 인력개발 프로그램, 장비산업 육성의 3요소의 순환적 연계 필요 } \\
\text { - 전국 규모의 통합 요트대회 개최를 통한 인지도 형성 } \\
\text { - 럭스리 요트 체험, 다이빙 및 낚시 등 해양레포츠와의 접목 필요 } \\
\text { - 부품, 엔진, 액세서리, 인테리어, 설계 등의 국내 기술개발 필요(개발비가 높아 대부 } \\
\quad \text { 분 수입이나 외주에 의존함) } \\
\text { - 요트 관리 업체 육성과 요트 학교와 체험장 확대를 통한 소비 장려 } \\
\text { - 해당 지역만의 고유한 해양레저장비 디자인 필요 }\end{array}$ \\
\hline $\begin{array}{c}\text { 인프라 } \\
\text { 및 시설 }\end{array}$ & $\begin{array}{l}\text { - 해양레저장비 업체의 지속성을 위해서는 선착장, 마리나 시설 및 설비, 배송, 상가 } \\
\text { 및 진수시설과 편의시설 등이 갖추어진 곳이 적당함 } \\
\text { - 전기 동력을 이용한 친환경 기술을 활용할 수 있는 인프라 구축 } \\
\text { - 해양레저장비산업을 위한 부지는 약 } 3,000 \sim 10,000 \text { 평 정도가 적당 }\end{array}$ \\
\hline $\begin{array}{l}\text { 인력 } \\
\text { 양성 및 } \\
\text { 교육 }\end{array}$ & $\begin{array}{l}\text { - 해양레저장비 업종 자격증 취득 시 기술사 대우를 받을 수 있는 방안 마련 } \\
\text { - 해외 연수 등 현장실무 교육과 특성화 고교 및 대학의 연계 } \\
\text { - 자체적으로 주로 교육을 실시하고 있고 동호회는 권장함 }\end{array}$ \\
\hline $\begin{array}{l}\text { 홍보 및 } \\
\text { 마케팅 }\end{array}$ & $\begin{array}{l}\text { - 대부분 해외 마케팅은 적극적이지 못하지만 해외는 주로 구미, 유럽과 동남아, 국내 } \\
\text { 는 부산, 제주 등 해양리조트 단지가 형성된 곳이 주요 목표 시장임 } \\
\text { - 전시회, 드라마(영화)나 마케팅 전문회사와의 협력을 통한 홍보 마케팅 필요 } \\
\text { - 호화요트 시장 수요와 아메리카스컵 요트 대회 시장 수요에 대비하여야 함 }\end{array}$ \\
\hline
\end{tabular}


는 현실적인 지원책이 필요하다는 응답이 많았 다. 또한 지자체는 지역 어민들과의 마찰을 해결 할 수 있는 방안과 어민들의 해양레저산업에 대 한 마인드 형성을 위해 어민들에 대한 해양레저 교육을 실시할 필요가 있다고 응답하였다. 한편 으로는 해양레저장비를 소비할 수 있는 소비 장 려 정책이 뒷받침되어야 해양레저장비산업이 활 성화 될 수 있을 것으로 생각하고 있었다. 제주 에 위치하고 있는 L_Marine 업체는 제주도의 환 경을 고려한 인허가 절차가 필요하다고 응답하였 다.

둘째, 해양레저장비산업 활성화를 위한 법과 제도에 대해서는 규제완화를 원하고 있었다. 구 체적으로, 해양레저장비와 관련된 저렴하고 다양 한 보험이 활성화될 필요가 있고, 요트와 관련된 절차, 행정 등의 규제가 간소화될 필요가 있다고 응답하였다. 특히 우리나라에서 요트는 호화사치 품으로 인식되어 요트 구입 시 과다한 세금부과 로 인해 요트 수요가 활성화되지 않는다고 응답 하였다. 또한 해양레저장비 소비자들이 해양레저 관광활동에 참여할 때 신고 제도를 간소화할 필 요가 있다고 하였다. 마지막으로 해양레저장비는 $\mathrm{FRP}$ 를 소재로 하는 장비가 많기 때문에 폐기 등 의 환경 문제도 해결해야할 문제로 인식하고 있 었다.

셋째, 콘텐츠, 프로그램 및 운영 시스템 측면에 서 해양레저장비업체는 부품, 인테리어, 설계 등 대부분의 기술과 장비들을 외국 업체나 외주를 통해 공급받는 시스템으로 운영되고 있었다. 이 는 기술개발과도 연관이 있는데 향후 해양레저산 업의 발전 가능성을 고려하여 정부의 적극적인 지원이 필요할 것이다.

해양레저장비산업 활성화를 위해서는 전국 규 모의 통합요트대회를 개최할 필요가 있고 해당 지역의 이미지를 고려한 디자인이 필요하고 세일 링 이외에 다양한 체험 등을 제공할 수 있는 콘 텐츠 구성이 필요하다고 응답하였다. 또한 지속 성 측면에서 요트 학교 등을 확충하여 소비를 장
려할 필요가 있고 요트 관리 업체도 육성할 필요 가 있을 것으로 분석되었다.

넷째, 인프라 및 시설에 대한 요구사항으로는 장비산업과 함께 필요한 시설로는 마리나, 상가 및 진수시설, 편의시설, 배송 등 종합적 인프라 시설이 갖추어져야 해양레저장비산업도 함께 활 성화 될 수 있을 것으로 인식하고 있었다. 또한 제주도에서는 전기 동력을 활용한 친환경 부품의 개발이 적절할 것으로 응답하였다. 해양레저장비 산업을 유치하기 위해 필요한 부지는 약 3,000 평 에서 1 만평 정도가 적절하다고 응답하였다.

다섯째, 인력 양성 및 교육에 관해서는 대부분 자체적으로 해결하는 것으로 분석되었다. 특히, 해양레저장비산업은 대표적인 3D 업종이라는 인 식이 높기 때문에 이직률이 높은 산업이다. 따라 서 기술사 수준의 대우를 받을 수 있는 정부의 대책 마련이 시급하다. 현재는 대부분의 업체들 이 자체 교육을 실시하고 있지만 향후 체계적인 장비산업 인력 양성과 교육을 위해서는 해외 연 수 등 현장실무 교육이 필요하고 특성화 고교나 해양레저장비 학과와의 연계가 필요할 것이다. 또한 직원들이 다양한 해양레저관광활동에 참여 하여 실무적인 감각을 익힐 수 있도록 동호회 활 동을 장려할 필요가 있을 것이다.

마지막으로 인터뷰 응답 업체들은 해양레저장 비에 대한 홍보나 마케팅 활동은 예산 문제로 거 의 하지 못하는 것으로 분석되었다. 동호회를 통 한 홍보도 부족한 것으로 분석되었다. 주요 수출 국으로는 호주, 뉴질랜드, 미국, 동남아, 중국 등 으로 분석되었고, L_Marine는 제주, 부산 등 해 양리조트 단지가 주요 시장이라고 응답하였고 Y_In은 국내 펜션시장을 주요 시장으로 생각하고 있었다. 향후에는 한국의 해양레저장비산업은 조 선 산업의 인지도를 이용하여 전시회 참여나 마 케팅 전문회사와의 협력을 통한 홍보 마케팅 전 략을 추진할 필요가 있다고 응답하였다. 또한 외 국의 호화요트 시장수요에 대비해야하고 한류 등 을 활용한 홍보 방안도 필요할 것으로 분석됐다. 


\section{3. 전문가 자문회의 조사 사례 연구 분석}

전문가 자문회의에서 제주도의 해양레저장비산 업 추진 방향은 기간을 두고 몇 단계로 진행하는 것이 타당하다는 의견에 합의를 하였다. 1 단계에 서는 제조업은 취약하지만 지리적인 위치에서 강 점을 살려 해양레저관광활동과 자연, 문화자원을 활용한 콘텐츠 개발이 필요한 것으로 분석되었 다. 또한 일본, 홍콩, 동남아 등의 중간 기착지로 써 해양거점지역으로 중요한 지점에 위치하고 있 다. 따라서 이러한 지리적 이점을 살려 중간 기 착지로서 주유나 식음료 구입 및 수리 등 유지 보수에 집중한다면 제주도가 해양레저관광의 최 적지로써 인지도를 가질 수 있을 것이라는 의견 에 동의하였다. 2차적으로 제주도의 해양레저에 대한 인지도가 높아지면 자연스럽게 해양레저장 비업체가 제주도에 입주할 것으로 예상할 수 있 다. 이를 위해 마리나 시설의 보완, 해양레저관광 서비스 산업의 확충 등의 과제 해결이 필요할 것 으로 분석되었다. 또한 2012년 2월부터 제주도가
동북아시아를 연결하는 크루즈 모항으로서(경향 신문, 2011) 역할을 하기에 적합한 곳으로 지적하 였다.

제주 마리나 항 개발 방향은 제주의 이미지를 고려하여 친환경 수리업체를 유치하고 클럽하우 스, 각종 이벤트 프로그램을 포함하여 개발할 것 을 권장하였다. 제주도 해양레저관광 수요 장려 방안으로는 제주도에 입도하는 요트를 위한 요트 관광 코스 개발 차원에서 해양레저지도 제작이 필요하고 체류기간 연장을 위해 연계관광코스 개 발이 필요할 것으로 분석되었다. 또한 지역주민 의 해양레저에 대한 관심 유도가 필요할 것으로 분석되었다. 경남 남해군은 군민 전체가 해양레 저관련 자격증 취득이라는 목표아래 행정직 공무 원이 우선적으로 자격증을 취득하는 노력을 경주 하고 있다. 국제보트 쇼 등의 유치도 해양레저 수요 장려를 위한 방법으로 제안하였다.

인력 양성방안으로는 관련 연구기관 및 대학과 지역이 연계하는 방안이 필요하고, 해양레저장비

<표 6> 전문가 자문회의 분석 결과

\begin{tabular}{|c|c|}
\hline 구분 & 분석 내용 \\
\hline $\begin{array}{l}\text { 제주 } \\
\text { 해양레저장비 } \\
\text { 산업의 방향 }\end{array}$ & $\begin{array}{l}\text { - } 1 \text { 단계 인지도 형성을 통해 2단계 제조업 유치 중심으로 점진적 사업추진 } \\
\text { - 제주도의 세계자연유산 선정, 생물권보전지역 지정, 세계 지질공원 인증 등 친 } \\
\text { 환경 이미지를 활용한 관광 콘텐츠 활용 } \\
\text { - 크루즈 모항과 요트투어 연계 }\end{array}$ \\
\hline $\begin{array}{l}\text { 제주 마리나 } \\
\text { 항 개발 방향 }\end{array}$ & $\begin{array}{l}\text { - 제주도는 친환경 이미지가 강하기 때문에 친환경 수리업체 유치 } \\
\text { - 최근 마리나 트렌드는 계류장, 쇼핑, 숙박시설과 더불어 환경 시스템을 겸비한 } \\
\text { 요트 수리시스템과 클럽하우스, 이벤트 등을 포함함 }\end{array}$ \\
\hline $\begin{array}{l}\text { 해양레저관광 } \\
\text { 수요 장려 } \\
\text { 방안 }\end{array}$ & $\begin{array}{l}\text { - 해양레저지도 제작을 통한 요트관광 활성화 } \\
\text { - 지역주민의 해양레저관심 유도 } \\
\text { - 중국 관광객 대상 요트 관광상품 개발 } \\
\text { - 국제보트 쇼 유치 }\end{array}$ \\
\hline $\begin{array}{l}\text { 중앙정부의 } \\
\text { 지원 유도 및 } \\
\text { 인력 양성방안 }\end{array}$ & $\begin{array}{l}\text { - 해양레저관련 단체장 협력 } \\
\text { - 관련 학과와 산학협력 유지 } \\
\text { - 관련 연구기관 및 대학의 지속적 교육과 연구 }\end{array}$ \\
\hline $\begin{array}{c}\text { 해양레저장비 } \\
\text { 업체 유치 시 } \\
\text { 주의사항 }\end{array}$ & $\begin{array}{l}\text { - 기업 유치 시 투자 수익에 대한 고려 } \\
\text { - 외부 기업 유치 시 무료 지원 요청에 대한 대응 방안 모색 } \\
\text { - 전통적인 조선업 관련 업자들의 관심 유도 } \\
\text { - 지역 어촌계와의 갈등 해소 방안 모색 } \\
\text { - } \mathrm{FRP} \text { 처리 등의 환경 오염 문제 해결 방안 모색 }\end{array}$ \\
\hline
\end{tabular}


업체 제주도 유치 시 주의사항으로는 기업 유치 시 투자 수익에 대한 고려가 필요하며, 양식장 등 어로사업을 주업으로 하고 있는 지역 어촌계 와의 갈등 해소 방안 모색도 중요한 문제로 제시 되었다. 또한 FRP 처리 문제로 폐선을 이용한 어 초 활용 등의 방안도 제안되었다.

\section{4. 해양레저장비산업 육성 방안 조사 분석 시사점}

이상의 조사 분석을 통해 향후, 제주도 해양레 저장비산업 유치를 위한 시사점을 제안하였다. 주요 시사점으로 우선 제주도는 1차적으로 수리 및 중간 기착지로써 해양레저산업의 이미지를 부
각시킨 후 점차적으로 해양레저장비산업을 유치 할 필요가 있다. 특히 친환경 이미지가 강하기 때문에 환경 친화적인 세계적 추세에 맞추어 해 양레저장비산업을 유치하더라도 스마트그리드 산 업단지와 연계하여 전기엔진 등을 장착한 레저장 비산업을 육성해야할 것이다. 해양레저산업 홍보 를 위해서는 제주도의 MICE산업과 연계하여 국 제보트쇼 등을 개최할 필요가 있다. 또한 해양레 저장비산업 유치 시 환경을 고려하여 부지 등을 제공하여야 한다. 이는 기존 중문 등의 마리나 시설을 적극 활용하여 환경적으로 최대한 피해를 주지 않는 방향으로 전개되어야 할 것이다. 구체 적인 시사점은 <표 $7>$ 과 같다.

\section{<표 7> 해양레저장비산업 육성 방안 조사 분석 시사점}

\begin{tabular}{|c|c|}
\hline 구분 & 시사점 \\
\hline $\begin{array}{l}\text { 국내 - 외 } \\
\text { 사례 연구 }\end{array}$ & $\begin{array}{l}\text { - 해외 유명 보트 쇼 참가를 통한 홍보(지식경제부, 교육과학기술부, 문화체육관광부 } \\
\text { 등의 해외 공동 마케팅 필요) } \\
\text { - 친환경 장비산업 및 슈퍼보트 수리업체 지원 } \\
\text { - 환경을 고려한 해양레저장비업체 부지 규제완화 및 현실적 지원 보장 } \\
\text { - 산학연관 해양레저장비산업 육성 위원회 } \\
\text { - 인력양성을 위한 주변 대학 및 동호회 지원 } \\
\text { - 마리나 시설, 요트 생산단지, 요트스쿨, 요트전시관, 박물관, 첨단요트사업기술연구센 } \\
\text { 터 등과 이주 직원의 주거와 교육, 의료, 문화생활 등의 인프라 전반을 공급할 필요 } \\
\text { 가 있음 }\end{array}$ \\
\hline $\begin{array}{c}\text { 심층면접 } \\
\text { 조사 사례 } \\
\text { 연구 }\end{array}$ & $\begin{array}{l}\text { - 마리나 시설, 요트 유지·보수(정비, 수리) 업체 등 기본 인프라 확충 } \\
\text { - 부지 공급, 인건비 한시적 지원, 인허가 및 세제 관련 적극적 지원과 행정의 간소화 } \\
\text { 필요 } \\
\text { - 차별화된 제주만의 건실한 해양레저장비 업체 육성과 제주 고유 이미지를 활용한 } \\
\text { 요트 디자인 필요 }\end{array}$ \\
\hline $\begin{array}{c}\text { 전문가 } \\
\text { 자문회의 } \\
\text { 조사 사례 } \\
\text { 연구 }\end{array}$ & $\begin{array}{l}\text { - 제주도를 중간 기착지로서 유지 및 보수 중심에서 점진적 제조 산업으로 추진 } \\
\text { - 친환경 이미지를 통한 해양레저관광서비스 및 수리 산업 집중 } \\
\text { - 크루즈모항과 요트투어 연계(해양레저지도 제작) } \\
\text { - 기업 유치 시 기업의 투자 수익과 무료 지원에 대한 고려 } \\
\text { - 홍보를 위해 국제요트 쇼 유치, 중국관광객 유치 } \\
\text { - 지역 어촌계와의 갈등과 환경오염 문제 고려를 통한 지역주민 해양레저관심 유도 }\end{array}$ \\
\hline
\end{tabular}

\section{V. 제주도 해양레저장비 산업 육성 방안}

이상의 연구를 통해 제주도 해양레저장비산업 활성화를 위한 방안을 2차 제조 산업 기반이 미
약한 제주도의 특성에 맞게 제안하였다. 기항지 로써의 유지 및 보수 시설 구축(1단계), 해양레저 관광 인지도 구축(2단계), 해양레저장비산업의 집 적화(3단계)를 통해 최종적으로 해양레저관광객 이 원하는 해양레저관련 시설 및 인프라를 구축 
하는 단계로 전개되어야 한다. 이렇게 구축된 인 프라 및 시설은 제주도의 해양레저산업 브랜드 인지도 형성에 기여할 것이다([그림 1] 참조).

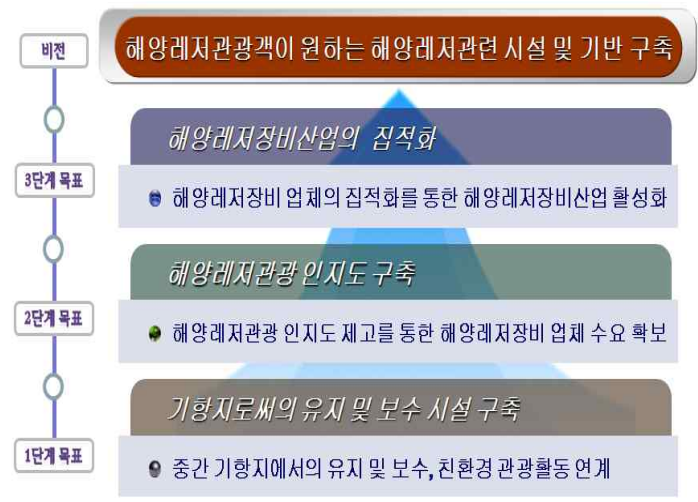

<그림 $1>$ 제주도 해양레저장비산업 육성 방향

1단계에서는 중국, 일본, 동남아 등지의 해양레 저관광객 유치를 통한 기항지로써의 역할을 수행 하고 기항지에서 요트 등 해양레저장비의 유지 및 보수가 가능한 시설을 마련하고, 친환경 제주 의 이미지를 활용한 관광활동 및 프로그램을 개 발하여야 한다. 2 단계는 해양레저관광 인지도 구 축을 위해 제주도를 찾는 해양레저관광객 수요를 확보하는 것이 우선이고, 해양관광객 수요의 증 가는 곧 해양레저장비 업체 수요의 증가로 이어 질 것이다. 따라서 1 단계 사업에서 기항지의 유 지 및 보수, 친환경 관광활동 개발을 통해 해양 레저관광객 유치가 우선적으로 필요하고 2단계 목표 달성을 위해서는 체계적인 홍보가 이루어져 야 할 것이다. 3 단계 목표는 해양레저장비산업의 집적화이다. 제주도가 해양레저관광에 대한 인지 도가 국내외적으로 확대되면 해양레저장비산업에 관심 있는 업체의 수요도 증가할 것으로 예상된 다. 특히 제주 해양레저장비산업을 지금 당장 유 치하는 것은 적절하지 않지만 제주도의 자연적, 지리적 조건을 고려한다면 향후에는 해양레저장 비 제작과 마리나 시설, 관광서비스가 통합된 형 태로 진행할 수 있을 것이다. 또한 해양레저보트
전망에 따라 슈퍼보트 및 최첨단 장비 산업도 유 치할 필요가 있고 이를 위해서는 법-제도적 지 원이 우선되어야 할 것이다. 또한 제주도 해양레 저장비산업을 위해서는 인프라, 법 - 제도, 콘텐츠 · 프로그램, 홍보·마케팅 관점에서의 전략들이 전제되어야 한다(최영근·이영진, 2011).

\section{1. 인프라 관점 육성 방안}

제주도 해양레저장비산업 인프라 구축을 위해 서는 '기항지로써 유지 및 보수 기반시설 확충', '요트 등 해양레저장비 관리 및 보관 기능 확대', '제주다운 마리나 시설 개발' 등을 고려할 필요가 있다. 우선, 요트 등 해양레저를 즐기는 국내 내 륙, 중국, 홍콩, 싱가포르, 일본, 동남아 지역으로 부터 방문하는 관광객을 위한 장비 유지 및 보수 기반시설을 확충하여야 한다(2단계). 해양레저를 즐기는 도중 발생할 수 있는 장비의 고장 시 중 간 기착지에서의 수리가 필요하고, 장비의 수리 및 정비 등은 개인 사업자도 쉽게 접근 가능한 분야이기 때문에 1 차적으로 제주도가 관심을 가 져야하는 분야이다. 또한 요트 등은 첨단 해양기 기 시스템, 인테리어, 친환경 에너지 관련 산업 등 다양한 기술이 융합된 장비이기 때문에 관련 업체도 함께 유치할 필요가 있다. 그리고 파워요 트나 해양레저장비의 경우 한 번 주유 후 이동 거리가 한정 되어 있기 때문에 중간에 유류수급 이 필요하다. 제주도가 해양기착지로써의 역할을 위해서는 해상 주유시설을 제공하여야한다(1단 계).

두 번째로 기항지인 제주도에 입항한 요트 등 해양레저장비를 관리 및 보관할 수 있는 서비스 를 제공하여야 한다. 이러한 서비스는 제주도가 안전한 요트계류장이라는 인지도를 형성하는 계 기가 될 수 있다. 이를 위해서는 안전하게 요트 등을 계류할 수 있는 시설과 레저장비를 책임지 고 관리해 줄 수 있는 인력이 필요하다(1단계). 계류장 관리 인력 및 안전관리 시설 확보는 제주 
도에 추가적인 고용창출 효과를 발생 시킬 수 있 다. 또한 인력 양성은 장기적인 시각에서 접근하 여야 한다. 성산고등학교 해양산업과, 제주고등학 교 등 특성화 고교와 제주대학교 레저스포츠 전 공학과, 한라대학 관광학부의 관광레저스포츠과, 제주관광대학 관광레저스포츠계열 레저스포츠전 공 등 수요자를 대상으로 하는 교육인력은 양성 이 되고 있지만 시설, 인프라 등을 체계적으로 관리할 수 있는 인력은 부족하다. 따라서 기착지 에서 계류 중인 요트 등 해양레저장비를 보관하 고 관리할 수 있는 전문 인력 양성을 위해 기술 계열 고등학교와 공학계열 대학이 함께 참여하여 야 한다(2단계).

마지막으로 제주만의 차별화된 마리나 시설 개 발을 통해 지역주민과의 마찰을 최소화하여야 한 다(1단계). 즉, 기존 어항 및 어민을 적극적으로 활용하여야 한다. 일본이 피셔리나 사업에 실패 한 이유 중 하나는 양식장 등과 요트 항로가 겹 쳐 지역 어촌계와의 마찰이 심화되었기 때문이 다. 제주도도 최근 해군기지와 크루즈항로 문제 로 이러한 마찰이 발생하고 있다(제주의소리, 2011). 제주도의 경우 양식 등 어로사업이 많지 않지만 어항의 피셔리나 전환에 있어 어업인들의 이익을 존중하고 어업활동을 최대한 존중하는 범 위 내에서 상호협약 등을 제정하여 협력적으로 시행하여야 한다. 또한 보상만으로 어업인들이 소득을 보전할 것이 아니라 자율적 직·간접적인 참여와 어선을 운영할 경험과 지식을 가지고 직 접 해양레저 종사자로 전환하도록 유도하여 지속 적이고 실질적인 소득을 얻도록 이들을 전문 인 력으로 고용하여야 한다.

\section{2. 법·제도 관점 육성 방안}

법·제도분야에서는 국민들이 해양레저장비 구 입 시 정부는 금융지원을 위한 제도를 마련하고 세제관련 규제를 완화(1단계)하여야 한다. 또한 해양레저 및 해양문화관광 교육기관 설립을 통한
해양레저관광산업의 전문 인력을 양성할 필요가 있다. 우리나라는 아직까지 요트 등을 개인이 구 입하면 사치라는 국민의 인식도 문제이지만, 이 러한 여론으로 인하여 요트 구입에 부과되는 세 금도 선진국에 비해 높다. 해양레저관광활동을 위한 레저장비 초기 구입에 대한 부담은 아직 국 내의 해양레저장비산업이 활성화되지 않았기 때 문에 수입 요트 등 구입 시 취- 등록세 비중이 높다. 따라서 선진국에서 이미 운영 중인 렌탈, 팩토링, 쉐어링 등 금융제도를 통한 간접 지원방 식도 고려해볼 수 있다. 유럽과 미국의 경우 레 저보트를 구매함에 있어 개인이 전액을 지불하고 구매하는 경우는 전체거래의 약 $20 \%$ 정도이며, 나머지 $80 \%$ 는 차터회사와 연계된 팩토링을 이용 하여 레저보트를 구매하고 있다. 특히 영국과 호 주의 경우 이를 통하여 레저보트를 구매하는 경 우 회계상 비용처리를 인정해 주어 소득세 경감 효과로 세제 지원도 하고 있다. 이러한 제도적 지원은 해양레저관광지로써 제주도의 인지도를 높일 수 있는 계기가 될 것이다.

두 번째로 해양레저관광 전문 인력 양성을 위 한 교육기관 설립이 필요하다(2단계). '해양수산 발전기본법'에 의해 수립된 '제 2 차 해양수산발전 기본계획(2011 2020) - 2020 해양한국 비전’의 5 대 추진전략에는 '미래형 고품격 해양문화관광의 육성'이 있는데 이를 위해서는 해양관광 인력 양 성이 선행되어야 한다. 해운인력양성은 한국해양 대학교, 부경대학 등이 언급되고 있지만 해양문 화관광 관련 교육기관은 여전히 부족하다. 따라 서 제주지역 소재 대학이 해양문화관광 전문 인 력 양성 교육기관으로서 먼저 인식될 수 있도록 지역 내 산.학·관이 적극적으로 참여하고 지원하 여야 한다. 전문 인력 양성을 위해서는 '스포츠산 업진흥법'에 의한 스포츠산업 전문 인력 양성기 관 및 스포츠산업지원센터 지정을 받아야 하고, 이를 토대로 '해양수산발전기본법' 제 35 조에 의한 재정지원을 확보하여야 할 것이다. 


\section{3. 콘텐츠 - 프로그램 관점 육성 방안}

해양레저장비산업 활성화를 위한 콘텐츠·프로 그램은 해양레저장비 중고품이 많은 국내 현실에 비추어 중고 해양레저장비 거래를 위한 국제거래 소를 설치하여 (가칭)해양레저 중고장비 거래박 람회를 개최(1단계)하고, 크루즈 모항과 연계한 친환경 프로그램 개발이 필요하다. 수상오토바이, 요트 등 대부분의 해양레저장비는 수입에 의존하 고 있어 장비의 제조, 수리 등도 중요하지만 중 고 장비에 대한 처리 문제가 대두된다. 이 때문 에 이러한 장비에 대한 효과적인 처분 방법으로 중고거래박람회를 개최하고 박람회 개최 시 선박 금융, 관련 장비 및 용품 등도 함께 거래한다면 해양레저장비시장이 활성화뿐만 아니라 환경문제 도 다소 해결되어 제주도의 이미지와도 부합될 수 있다. 특히, 홍콩, 싱가포르 등은 무비자와 무 관세 원칙이 적용되어 고가의 비용부담 없이 장 비 구입이 가능하므로 이들 무관세 국가를 주요 목표시장으로 거래박람회를 개최하는 것도 방법 이다. 또한 경남, 부산 등 몇몇 지자체에서 해양 레저장비관련 보트 쇼나 전시회 등을 추진 중이 나 규모나 인지도가 낮다. 이에 경기도는 국제 요트대회인 월드 매칭 레이싱 투어와 공동개최를 추진하여 인지도를 높이고 있다. 해외의 LA 보트 쇼 등은 55회째 개최될 만큼 인지도가 높다. 따 라서 제주도의 친환경 이미지를 내세워 해외 유 명 보트 쇼와 연계하여 해양레저장비 관련 전시 회 또는 박람회(1 3단계) 등을 개최할 필요도 있 다. 이는 제주의 해양레저장비산업의 홍보에도 기여할 것이다.

둘째, 내년부터 제주도를 모항으로 본격적으로 운항예정인 동남아 크루즈를 활용하는 친환경 프 로그램을 개발할 필요가 있다(1단계). 제주도의 자연환경 자체만으로 관광매력을 창출하기에는 한계가 있고 육상 관광산업은 정체단계이다. 이 에 최근 제주도는 $\mathrm{MICE}$ 관련 프로그램 개발이 추진되고 있고 2012년부터 제주항에 중국, 일본,
한국을 잇는 5 만 톤급 크루즈선이 운항하기 때문 에 이에 대비한 기항지 관광 프로그램 개발이 필 요하다. 따라서 이벤트 등 적극적 활동을 할 수 있는 프로그램을 개발하고 $\mathrm{MICE}$ 선도 사업단이 개발한 테마파티, 팀 빌딩, 스마트그리드 연계 코 스 등 다양한 $\mathrm{MICE}$ 관련 상품 및 코스 등의 프 로그램을 해양레저산업과 연계할 필요가 있다.

\section{4. 홍보 - 마케팅 관점 육성 방안}

제주도 해양레저장비산업 홍보와 마케팅을 위 해서는 유명 연예인이 출연하는 드라마나 영화를 활용할 필요(2단계)가 있고 요트 산업에 대한 부 정적 이미지를 개선하여야 한다. 특히, 동남아 등 지에서는 한류의 인지도가 높기 때문에 한류 연 예인들이 출연하는 드라마나 영화 제작 시 제주 도의 해양레저관광 시설이나 행정적 지원을 하는 것은 제주지역의 해양레저관광의 우수성을 적극 알리고 이를 통해 해양관광의 잠재시장인 중국 등 외국관광객 유치를 위한 마케팅 활동이 강화 될 수 있다. 한 예로 '나쁜남자'가 김녕요트투어 에서 촬영되어 인지도가 높다. 지원 재원은 문화 체육관광부와 지식경제부 등이 협력하여 드라마/ 영화 제작비 등을 지원할 필요가 있다.

둘째, 요트산업에 대한 부정적 이미지를 개선 하기 위하여 제주에서 해양레저산업이 적절하다 는 당위성을 홍보할 필요(2단계)가 있다. 10 15 년 전의 국내 골프는 귀족 스포츠로 인식되었지 만 지금은 대중레저로 인식하는 경향이 높다. 해 양레포츠 중 요트 등도 귀족, 호화 등 다소 사치 스런 이미지로 인식되고 있지만 녹색에너지인 바 람 등을 이용하기에 가장 적합한 레저가 해양레 저이기 때문에 환경오염을 최소화할 수 있는 레 저 활동으로 인식 전환이 가능하다. 또한 제주도 는 사면이 바다이고 적당한 바람이 불어 해양레 포츠를 즐기기에 적절한 기후조건이기 때문에 해 양레저장비산업 추진 당위성에 대한 체계적인 연 구와 홍보가 필요하다. 
마지막으로 해양레저사업을 진행할 때 가장 문 제가 되는 부분이 지역주민과의 갈등이다. 한 지 역의 산업은 지역민의 동의가 있어야 갈등 없이 진행될 수 있다. 특히 관광산업의 경우 이해관계 가 복잡하여 갈등양상이 더욱 심화될 수 있다. 따라서 해양레저산업이 제주도에 가져다 줄 수 있는 편익이 무엇인지에 대한 지속적 홍보를 주 민 간담회나 제주도 차원의 제주방송 등을 통해 홍보할 필요가 있다. 또한 지역민 스스로 친환경 산업이라는 자부심을 가질 수 있도록 지역민의 산업 참여도 적극 고려하여야 할 것이다.

$<$ 표 8> 제주도 해양레저장비산업 육성 방안 요약

\begin{tabular}{|c|c|}
\hline 관점 & 제안 내용 \\
\hline $\begin{array}{l}\text { 인프라 } \\
\text { 관점 }\end{array}$ & $\begin{array}{l}\text { - 기항지로써 유지 및 보수 } \\
\text { 기반시설 확충 } \\
\text { - 요트 등 해양레저장비 관리 및 } \\
\text { 보관 기능 확대 } \\
\text { - 제주다운 마리나 시설 개발 }\end{array}$ \\
\hline $\begin{array}{l}\text { 법 } \\
\text { 제도 } \\
\text { 관점 }\end{array}$ & $\begin{array}{l}\text { - 해양레저장비에 대한 금융지원 } \\
\text { 제도 개발 } \\
\text { - 해양레저관광산업 전문 인력 } \\
\text { 양성기관 설립 추진 }\end{array}$ \\
\hline $\begin{array}{l}\text { 콘텐츠 } \\
\text { · 프로 } \\
\text { 그램 } \\
\text { 관점 }\end{array}$ & $\begin{array}{l}\text { - 해양레저 중고장비 국제거래 } \\
\text { 박람회 개최 } \\
\text { - 크루즈 모항과 연계한 친환경 } \\
\text { 프로그램 개발 }\end{array}$ \\
\hline $\begin{array}{l}\text { 홍보· } \\
\text { 마케팅 } \\
\text { 관점 }\end{array}$ & $\begin{array}{l}\text { - 드라마 및 영화산업 연계 홍보 } \\
\text { - 요트산업에 대한 부정적 이미지 } \\
\text { 개선 방안 }\end{array}$ \\
\hline
\end{tabular}

\section{VI. 결 론}

최근 전 세계적으로 육지관광의 포화상태로 해 양관광에 대한 관심이 높아지고 있다. 해양은 밝 혀지지 않은 해저의 신비로움과 풍부한 자원을 인간에게 제공하고 있다. 특히 제주도는 세계자 연유산 선정, 생물권보전지역 지정, 세계 지질공 원 인증 등과 더불어 올해는 세계 7 대 자연경관 에 선정될 만큼 자연경관이 수려하고 환경적으로 도 잘 보전되어 있다. 더욱이 사면이 바다인 제
주도는 해양자원 또한 풍부하고 약 13억이 넘는 인구를 가진 중국뿐만 아니라 일본, 동남아 등 큰 배후 시장을 가지고 있어 해양레저관광산업의 성장 잠재력은 매우 크다고 할 수 있다.

본 연구는 이러한 제주도의 지리적, 자연적 조 건을 토대로 해양레저관광활성화를 전제로 해양 레저장비산업을 어떻게 활성화 시킬 것인지에 대 해 고찰하였다. 사례연구방법을 토대로 문서정보, 구조화된 인터뷰, 개방형 인터뷰 자료원을 통해 자료를 수집하여 제주도 해양레저장비산업 육성 방안을 제안하였다. 제주도의 산업 기반의 취약 성으로 인해 제안을 3 단계로 진행하였다. 1 단계 에서는 중국, 일본, 동남아 등지의 해양레저관광 객 유치를 통한 기항지로써의 역할을 수행하는 목표를 설정하였다. 2 단계는 해양레저관광 인지 도 구축을 위해 제주도를 찾는 해양레저관광객 수요 확보라는 목표를 수립하였다. 해양관광객 수요의 증가는 곧 해양레저장비 업체 수요의 증 가로 이어질 수 있기 때문이다. 마지막 3단계 목 표는 해양레저장비산업의 집적화이다. 제주도가 해양레저관광에 대한 인지도가 국내외적으로 확 대되면 해양레저장비산업에 관심 있는 업체의 수 요도 증가할 것으로 예상되고 이에 따라 해양레 저장비산업이 자연적으로 활성화 될 수 있을 것 으로 예상된다.

구체적으로 인프라 관점에서 '기항지로써 유지 및 보수 기반시설 확충', '요트 등 해양레저장비 관리 및 보관 기능 확대', ‘제주다운 마리나 시설 개발'을 제안하였다. 법-제도 관점에서는 '해양 레저장비에 대한 금융지원 제도 개발', '해양레저 관광산업 전문 인력 양성기관 설립 추진'을 제안 하였고, 콘텐츠- 프로그램 측면에서는 '해양레저 중고장비 국제거래 박람회 개최', '크루즈 모항과 연계한 친환경 프로그램 개발'을 제안하였다. 마 지막으로 홍보-마케팅을 위해 '드라마 및 영화 산업 연계 홍보', '요트산업에 대한 부정적 이미 지 개선 방안'을 제안하였다.

제주도가 2차 산업 기반이 약하다는 단점을 가 
지고 있지만 다른 지역에서 가지지 못한 해양레 저관광 매력 물을 많이 가지고 있다. 이러한 장 점들을 잘 활용한다면 향후, 세계적인 해양레저 도시로 성장할 수 있을 것으로 예상된다.

끝으로, 본 연구에서 제안한 부분들을 통해 가 까운 미래에 해양레저관광객들이 제주도에서 생 산된 해양레저장비를 이용하여 레저를 즐길 수 있기를 기대해 본다.

\section{참고 문헌}

경남발전연구원(2007). 남해안시대 해양레저스포 츠 활성화 기본구상.

경남발전연구원(2009). 경남의 요트산업 육성방안. 경남요트교육통합시스템(2012).

http://www.gsndyacht.org.

경향신문(2011). 제주 모항 국제 크루즈선 중 - 일 - 러운항, 9월 27일.

굿데이(2011). 호화요트 수리는 오클랜드, 최대 크루즈는 웰링턴 입항, 3월 3일.

네이버백과사전(2012). http://100.naver.com. 뉴시스(2008). 내년 대한민국 국제요트대전 통영. 고성서 개최, 11 월 3 일.

박성현(2005). 국내 요트 산업의 현황과 문제점, 해양환경안전학회지 11(1), 47 52.

법률지식정보시스템(2012).

http://likms.assembly.go.kr/law/jsp/main.jsp. 부산발전연구원(2009). 부산지역 해양레저장비산 업 육성방안-요트산업 육성을 위한 기초연구.

월간 해양과조선(2011). 출사표를 던진 국내 해양 레저장비 산업의 현황과 전망은?, 5월 17일.

이영진(2009). 해양 레저관광행동 영향요인 구조 분석: Hedonic과 Utilitarian의 조절효과를 중심 으로, 한양대학교 대학원 박사학위논문.

이영진 · 송영민 - 이광표(2011). 강릉시 어촌관광 체 험 프로그램의 유형화, 수산해양교육연구 23(4), 695 708.

제주특별자치도의회 농·수·축 지식산업위원회
(2010). 제주 해양생태 - 레저관광 활성화 방안 모색. 공동 심포지엄 논문집, 제주대학교 국제 교류회관 대회의실, 10 월.

제주의소리(2010). 제조업 빈약한 제주에서 해양 레저 장비 생산, 12월 7일. (2011). 국방부, 제주해군기지 크루즈검 증위 참여 미적미적, 11 월 22일.

중소조선연구원(2008). 해양레저장비산업 현황 및 전망. 지식경제부 지역발전포럼 자료집, 8 월.

(2010). 해양레저장비산업 육성방안.

지삼업 - 김용재·이재형(2005). 어촌어항을 활용 한 해양스포츠 체험관광 활성화 방안, 수산해 양교육연구 17(1), 86 105.

지식경제부(2009a). 해양레저장비산업 활성화방안. (2009b). 해양레저장비산업의 신수종산 업으로 추진, 경기 국제보트쇼·세계요트대회 개막식 치사 보도참고자료.

동차조선과.

(2010). 해양레저장비산업 육성방안, 자

최영근 - 이영진(2011). 제주 해양레저장비산업 육성 방안, 제주발전연구원 정책연구 보고서(2011-1).

코트라(2009). 해외 주요국 레저보트산업 조사, 경기보트사업단.

한국조선공업협동조합(2012).

http://www.kosic.or.kr.

해양한국(2006). '2016 미래 국가해양전략' 주요 내용, 10월, 126 131.

(2010). 여름테마기획/(3-2) 해양레저 행 사들: 해양레저스포츠 경제효과 10 조원 규모, 7 월 28 일.

UK Trade \& Investment(2006). Marine IndustryNew Zealand,

http://www.uktradeinvest.gov.uk.

Yin, R. K.(2003). 사례연구방법, CASE STUDY RESEARCH: Design and Methods(3th)(신경식 • 서아영 역), 서울: 한경사.

- 논문접수일 : 2012년 03월 23일

- 심사완료일 : 1차 - 2012년 04월 03일

- 게재확정일 : 2012년 04월 05일 